\title{
The church as a moral agent: In dialogue with Bram van de Beek
}

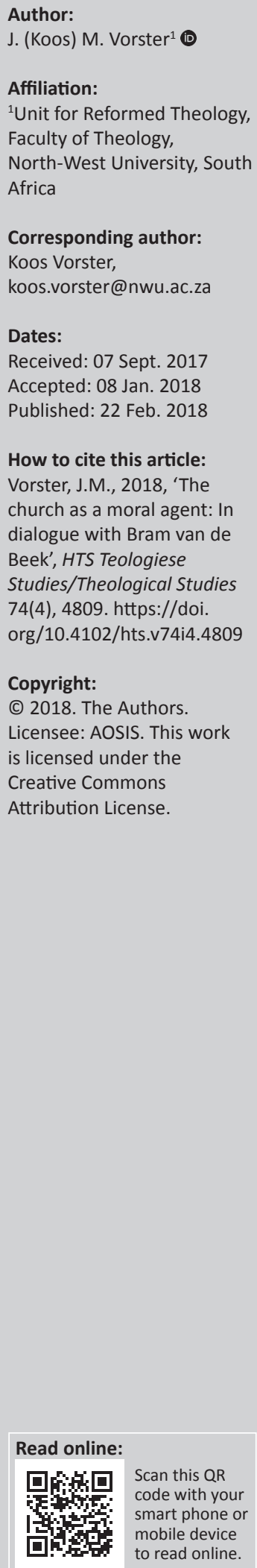

The latter part of the 20th century is known for a surge in the so-called 'genitive theologies'. Usually, a genitive theology has an ulterior motive, aiming at the transformation of a society or the promotion of sound politics and economy. In recent years, this trend culminated in public theology. The issue of religion with an ulterior motive was raised by Van de Beek in a seminal article focusing on theology without gaining anything from it as an answer to the surging genitive theologies of the latter part of the 20th century and the public theologies of today. Taking into account Van de Beek's critique against 'religion with an ulterior motive', this article explores the concept of the church as a moral agent in dialogue with Van de Beek. The central theoretical argument of this investigation is that Van de Beek's ecclesiology is valuable when defining the role of the church as a moral agent. However, the perspective of the Kingdom of God concerning the church can enrich one's views and can add value to his valid critique on public theology.

\section{Introduction}

The latter part of the 20th century is known for a surge in the so-called 'genitive theologies'. Usually, a genitive theology has an ulterior motive, aiming at the transformation of a society or the promotion of sound politics and economy. It is a 'theology of ...'. This era has seen a succession of theological enterprises, such as the theology of revolution (Shaull 1969), the theology of transformation (Verkuyl 1971), political theology (Fierro 1977) and the theology of liberation (Gutierrez 1985). In recent years, this trend culminated in public theology. With reference to several scholars, Bishop (2016) defines public theology as follows:

Public theology tasks Christians to stand up for the oppressed, welcome the stranger, and resist evil. It fights segregation and discrimination while also demonstrating Christian convictions in the public square. Just as Jesus transforms individuals on a personal level public theology attempts to transform society at a larger level. For example, Christians are to highlight the contemporary culture of mass consumerism to demonstrate its misguided desire. (p. 1)

The issue of religion with an ulterior motive was raised by Van de Beek (2005:526) in a seminal article focusing on theology without gaining anything from it as an answer to the surging genitive theologies of the latter part of the 20th century. His view was discussed by various scholars in the publication 'Religion without ulterior motive' (Van den Borght 2005). Van de Beek asks the question whether religion and the church should have an ulterior motive other than to worship and serve God. He advises against the notion that the Gospel should be made relevant from time to time to fulfil the needs of people in a particular situation. If people have to make the Gospel relevant, the Gospel is not the Gospel anymore. The Gospel is relevant by nature and always appropriate. In the expression of the Missio Dei, the church must act according to its nature - to be church and to have a message for seekers (Van de Beek 2012:111-112). From this point of departure, he criticises the traditional ecclesiological notions of theocracy, the church for the world, the prophetic testimony of the church and the seeking of the Kingdom of God as models of ecclesiastical involvement in society (Van de Beek 2012:113-131). His point of view with regard to the role of the church in society is discussed later in this article.

Taking into account Van de Beek's critique against 'religion with an ulterior motive', this article explores the concept of the church as a moral agent in dialogue with Van de Beek. The point of departure also includes the notion of public theology or genitive theology. The central theoretical argument of this investigation is that Van de Beek's ecclesiology is valuable when defining the social role of the church, but the perspective of the Kingdom of God concerning the church can enrich one's views and can add value to his valid critique on public theology. The discussion commences, therefore, with a critical reflection on the ecclesiology of Van de Beek. 


\section{The ecclesiology of Van de Beek}

Van de Beek discusses his view of the church within the ambit of pneumatology. ${ }^{1} \mathrm{He}$ connects the body of Christ with the spirit of Christ (Van de Beek 2012) in accordance with the Apostolic Confession - the church is perceived as part of the work of the Holy Spirit. This relationship between Spirit and church can be described as the backbone of his ecclesiology and determines his views on the existence and calling of the church. The Spirit gives shape to the new reality brought forward by Christ. The Spirit changes the church. Ecclesiology and pneumatology are indeed deeply intertwined and the church cannot, therefore, be defined as just a social sphere or a civil organisation that can act and be evaluated as a mere civil society. The church is more than a social group of people with a 'constitution' and a plan of action. Van de Beek's confirmation of the foundation of all aspects of the church in pneumatology is indeed valuable because of the fact that in this age of secularism the sacred nature of the church and its future are often forgotten and attempts to revive the church rest on mere sociological principles.

\section{The uniqueness of the church}

Van de Beek (2012:13) proclaims that the church is unique and a community that no longer belongs to members but to Christ. Believers are strangers and pilgrims in the world who no longer belong to the reality of this world but to the eschatological reality of Christ, and this reality is strange to the ways of the world. In this respect, he refers to the contributions of church fathers who highlighted the deep divide between the church and the world. The true existence of believers is in the eternal life. By baptism, believers are incorporated into the church and their old life of sin is no longer a part of them. Within the framework of the Apostolic Confession, Van de Beek discusses the holiness, catholicity, apostolicity and calling of the church. Of these attributes little can be seen in the life of the church through the centuries, but nevertheless these attributes constitute the uniqueness of the church. This uniqueness of the church must be taken into account in any assessment of the existence and role of the church in the world.

The uniqueness of the church determines the role of the church. The unique character of the church as a pilgrim in a hostile world should never be compromised by politics or ideologies. In this respect, Van de Beek warns against various proposed models of social action by the church. Firstly, he deals with the idea of an apostolate theology introduced by Van Ruler, Barth and Berkhof. In this model, the concept of the Kingdom of God is the foundation of the calling of the church to seek justice and peace in the world. The church must realise the reign of Christ in a broken world and a

1.Koopman (2012:887) distinguishes between the views of the 'earlier' and the 'later' Van de Beek. In his view, the earlier Van de Beek was less critical of the notion of public theology and proposed, in the words of Koopman, a 'Public Theology of suffering'. The 'later' Van de Beek warns against public theology because religion can easily be used to justify major wrongs (Koopman 2012:888). In this article, the critical view of the 'later' Van de Beek is emphasised, specifically in his book Lichaam en Geest van Christus (Van de Beek 2012), because it represents his position now and explains his main objections against religion with an ulterio motive of which public theology is one manifestation.
Christian culture and Christian social spheres should be cultivated. Van Ruler lauds Constantinian Christianity and supports colonialism, because all nations must be taught to Christianise their cultures and politics.

On this matter, Van de Beek refers to the influence of the ecclesiology of Barth on apostolate theology as Barth explained it in his commentary on Romans (Barth 1922). Barth reacted against the servitude of German Christianity concerning the social conditions of his time and especially with regard to the rising ideology of National Socialism. He proclaimed that God - revealed in Christ - cannot be coopted for human ideological or political endeavours. The church can, therefore, have only one Master and that is Christ. He rejected any form of natural theology (Brunner \& Barth 1946:84). He posited his own point of view in his wellknown publication Christengemeinde und Bürgergemeinde in 1946 (Barth 1946:15). The church must be the conscience of the state and the state should see in the church an example of justice and peace. The church must be a speaking church and should fulfil a prophetic calling aimed at the strengthening of the post-war society. He, therefore, exerted a potent influence on the development of a critical theology in the Netherlands.

Furthermore, Van die Beek refers to Berkhof as a further influence on the apostolate theology. In 1948, Berkhof was instrumental in the establishment of the World Council of Churches (WCC) and viewed the purpose of the WCC as the promotion of a just world order and new relations amongst nations. By promoting world peace, the church can be the light of the world and the salt of the earth. His ideas are explained in his influential 1959 publication (Berkhof 1959). He maintains that Christ provided a new purpose to the world by adding a new characteristic to relationships amongst people. This new characteristic is the struggle for the promotion of human dignity, freedom, peace, reconciliation and human rights. Christ renews the world on a continual basis and the church should be the vehicle of this ongoing process. The calling of the church is fundamentally a social calling. This new vision of the calling of the church was carried forward by the WCC and the World Alliance of Reformed Churches (WARC) during the latter part of the 20th century. Van de Beek (2012:108) criticises the essentials of this new calling because he perceives it as a new form of colonialism - the church knows what is good for the world. The church is part of the Missio Dei but should not have an own agenda. Although Christ has all the power on heaven and earth, this power is not assigned to the church. In this respect, he also disagrees with Moltmann's anonymous Christianity and theocracy.

Van de Beek deals with the phenomenon of anonymous Christianity with reference to Mouw (2000) and Rahner (1972:22-25) who approach the idea from different angles. These two authors are of the opinion that all people are seeking God. The church must, therefore, be present for people by serving the needs of people and must introduce 
God to seekers. Van de Beek's problem with this point of view is the notion that the church presents itself as a body who proclaims they know what is best: they know people better than they know themselves and they know what people long for (Van de Beek 2012:112). Moreover, this viewpoint entails that the Gospel should adapt to the needs of people. If the Gospel should be made relevant, it is not the Gospel anymore. His critique is more vigorous regarding the idea of theocracy, which historically manifested in four positions, namely that the church should decide what the state should do; the church and state are both under the authority of Scripture; the state and the Christian religion are totally interwoven; and that the state cannot claim absolute power because God rules over all spheres of life. In his view, theocracy can also be called 'ecclesiocracy' because the church decides what the state should do (Van de Beek 2012:113). In this respect, the question can be asked whether the view of Van de Beek is nuanced enough. Does every model he describes really suit the term 'theocracy?'

\section{Prophetic critique}

Van de Beek deals with the relationship between religion and politics, which both fall under the reign of God. This principle manifests in various political paradigms and has been highlighted in documents, such as the Barmen Declaration and the Confession of Belhar. These political paradigms and documents deal with the prophetic testimony of churches in contrast with the governments of today. The idea that the church has a prophetic calling is popular in modern theology, especially in the various existing models of public theology. These models are based on the actions of the prophets in the Old Testament who reprimanded the authorities about their injustices towards the poor and the vulnerable. Later on in his discussion, Van de Beek (2012:138) explains that the prophetic voice of the church and theocracy are essentially Old Testament in nature and he finds no grounding in the New Testament. In addition, he maintains that in comparison to the theocratic model, this model departs from a fundamental suspicion in the policies and actions of the state (Van de Beek 2012:119). He is hesitant to condone this model because of its embedded suspicion and the limitations placed on the calling of the church. The church cannot presume to know better than the state what is best for a society. The 'prophetic calling' of the church can violate the limitations of power, especially when the church wants to force a government to exert power to do what the church wants them to do. In all these models, the church acts as a 'bridge' to the world and an institute where ideals about politics should be pursued.

The same can be said about the 'church for the world' model. Van de Beek (2012:121) is of the opinion that this model contains colonial characteristics and was evident in the British missionary enterprise of the 19th century and recent American wars promoting a Christian Western civilisation. The testimony of the church coincides with colonial enterprises and the promotion of a Western culture. In this model, the church is portrayed as a small 'elite' force pushing ideas onto pluralist societies. Eventually, this can lead and has in certain situations led to religious violence. The idea of the church as a bridge to the world is fundamentally flawed, as this idea accentuates in various models the relationship between the church and the world and violates the unique character of the church as a Eucharistic community - the church is not the mystic body of Christ anymore because it is subservient to secular social ideals. The church should refrain from the promotion of political ideals and should rather act as a church in the world, praying for the government of the day and being an oasis for people in distress and need.

\section{The Kingdom of God}

Currently, the concept of the Kingdom of God is widely used as a paradigm for the social actions of the church (Vorster 2017b:15). Van de Beek (2012:126) pays attention to the viability of this model from his angle of approach, namely the Kingdom of God as an eschatological reality. He deals with the historical debate concerning the notions of the Kingdom of God as an immanent historical reality that should be realised by the social actions of people and the idea that the Kingdom of God is an issue of the future. Presently, the Kingdom theology has mainly a utopic character and the idea of Missio Dei is argued within this framework. With reference to the theology of the Church Fathers, he maintains that the Kingdom language is apocalyptic language. In Jesus, the Kingdom of God came. He receives all power in heaven and earth. The post-Easter events enable people to speak of Christ as the King and his rule over the whole cosmos. The Kingdom of God has a present and future meaning in the sense of the powerful reign of Christ and not as a social sphere. The language of the Kingdom of God is all about Christ. He is the Kingdom. The term 'Kingdom of God' cannot, therefore, still be used as it was used in the Gospels because the promises of the Kingdom were fulfilled in Christ.

According to Van de Beek (2012:130), the new actuality of this concept over the past century was caused by secularisation for two reasons. Firstly, the focus of people shifted from the future to the present and from heaven to earth. This tendency led to a contextualisation of the Christian faith. Christian faith became embedded in social actions and the promotion of justice and peace. The church became an institution of social responsibility. Secondly, a power shift occurred in Western society from the church to the state and social institutions. This power shift forced the church to seek ideological power. In this process, the idea of the Kingdom of God fits well. The church assumes that preaching the Kingdom of God leads to a powerful encounter with the powers of the world. The preaching of the Kingdom of God has to do with power. Van de Beek even ventures to say that the Kingdom theology of the 20th century granted more power to the church than the case with the Corpus Christianum in the Medieval Age. Now the church sets foot on the terrain of secular ideologies. The preaching of the Kingdom of God becomes more ideology than theology and leads to utopic thinking. 
Authority implicates the execution of power and that is the bread and butter of the state (Van de Beek 2012:132). If the church is in any way co-opted by the interests of the state, it becomes part and parcel of the power game. The church should function as an alternative community. In this respect, Van de Beek elaborates on the ecclesiology of Hauerwas. Hauerwas maintains that the church should be an alternative polis, a countercultural social structure (Hauerwas \& Willimon 1989:46). The church is a community that should be willing to suffer in the imitation of Christ and should be an alternative to the current political dispensation. This is the essence of the church and, in this way, the church will be a light to the world. According to Van de Beek, the ecclesiology of Hauerwas is a good representation of the role of the church in society promoted by Church Fathers, such as Tertullian, Hippolite and Origin. They professed pacifism and so does Hauerwas. Christians view themselves as strangers in the world. In the same way, Hauerwas (1995:53) defines the church as a colony, an island of one culture in the middle of another. When baptised, citizenship is transferred from one dominion to another, and believers become resident aliens in whatever culture they find themselves. Van de Beek (2012:135) justifies the view of the church as an alternative community by proclaiming that this idea was defended by early Christians and adds that nowhere in the New Testament can the command to Christians be found to transform the world. The church prayed for the government - a pagan government. Christians had no need for political transformation; they focused on self-sacrifice, servanthood, love and the sharing of their possessions with joy. ${ }^{2}$

According to Van de Beek (2012:135), the ecclesiology of Hauerwas is related to the views of the 1st century authors on the emergence of Christianity. There is, however, one point of difference which lies in the fact that Hauerwas (Hauerwas \& Willemon 1989:27) contends that the church as alternative community - can be described but not founded. Van de Beek explains that the Church Fathers had a reason for the existence of Christians and that is the Logos, Christ. The foundation of Christians is their existence in Christ. Christ is not the role model of Christians, but they are inspired by the fact that they die and are resurrected in him. They share in the life of Christ. Based on this viewpoint, Christians celebrate the Eucharist; they are united and willing to remain faithful until death. His critique on the ecclesiology of Hauerwas is that all these important elements remain vague. He obviously misses the

2.In the time of the application of apartheid in South Africa, the idea of the church as an alternative society was promoted by the missiologist Bosch (1991:172). He urged churches in the time of the struggle against apartheid to be an example of a community of racial harmony and of effective racial integration and to exert in this way an influence against apartheid in society. However, he did not view this mode as the only way of existence of the church. The church should also be a prophetic community. Another proponent of the idea of the church as an alternative community is Moltmann (1990:122) who speaks about the church as kontrastgemeinschaft and an Exodusgemeinde (see also Harvie 2009:34; Vorste 2014:157). Another South African theologian who entertains the same idea is Van Wyk (2015:347) with his notion of theologian who entertains the same idea is Van Wyk (2015:347) with his notion of the church as an 'exemplary community'. As such, the church is an example of the new world as God would like the world to be. The church is (and should be) a community where love, hope, liberation and reconciliation are received, shared and proclaimed in an exceptional way. The idea of the church as an alternative - and exemplary and moral community - has taken root in ecclesiology today and is worthy of further consideration. The question is, however, whether this idea can be proposed as the only characteristic of the church. eschatological perspectives in the ecclesiology of Hauerwas. Furthermore, Van de Beek concludes that, according to the viewpoint of Hauerwas, theology and ecclesiology are engulfed in ethics.

\section{The church as an eschatological reality}

Van de Beek (2012:137) states that the church is not just an alternative community but an eschatological reality. His view is based on the prophets in the Old Testament and apocalyptic material in Scripture. Apocalyptic eschatology differentiates between history and the Kingdom of glory. Earth and earthly time will be brought to an end and God will create a new heaven. This new heaven will change and enlighten the lives of Christians. Using the Old Testament in founding the relationship between the church and the world causes hermeneutical difficulties. Firstly, the Torah speaks to Israel of old and not to the nations of today. Appropriating the Old Testament, Torah neglects the idea that the Torah has been fulfilled in Christ. Secondly, the Torah can never be read without Christ. The 10 Commandments are only relevant when read within the context of Christ's death and resurrection. This principle applies to the caring of the poor and ceremonial laws. The viewpoint of Van de Beek in this regard is problematic and is critically discussed in the next section. Van de Beek reiterates that the church is the eschatological community of Christ and is, therefore, an 'other-worldly' community. The church has, therefore, nothing to do with the transformation of social structures (Van de Beek 2012:139).

\section{The missionary task of the church}

In this respect, Van de Beek (2012:141) repeats his view that Christians are aliens and strangers in the world on a pilgrimage and the mission aspect of this pilgrimage does not entail that the church has to set up the Kingdom. 'Mission' is to refer to the death and resurrection of Christ and his vindication over the powers of the world. He instructed his disciples and apostles to perform 'mission'. The purpose of mission is not to promote the Kingdom but to make the world church. That is what the term 'catholicity' means. It is true that Christ preaches the Kingdom, but in a historical context, the Kingdom is the church. The church is the visible and only manifestation of the Kingdom. Mission entails that Christians should live in a certain way to be seen as the light of the world. Furthermore, the church has limitations. Everything that is described as church is not church. Heresies and schism distort the church. The church has, therefore, a mixed character. Not all Christians are Christians out of an inner conviction. Van de Beek refers in this regard to Augustine's idea of the 'ecclesia permixta' (Van de Beek 2012:151). Being part of the church does not entail an official membership like being a member of a social club but by living as a Christian. After all, the tree becomes known by its fruit.

Up to this point, Van de Beek discusses the relationship between the church and the world. The church as a 
community of strangers and pilgrims does not transform the world nor does it realise the Kingdom of God in social and historic terms. The church exists for the glory of God and observes religion without an ulterior motive. It cannot therefore function as a moral agent other than being a community with a unique identity embedded in the lifestyle of Christians. In the following section, the thesis of Van de Beek is discussed from the perspective of the Kingdom of God and the reign of Christ.

\section{Discussion}

\section{Points of departure}

In the discussion with Van de Beek, several points of departure should be stated:

- Van de Beek is correct in his assessment of public theology. Theology should not be engulfed in public theology; the reason is that if it does so, then theology becomes mere ecclesiology and all theological texts are interpreted within a certain historical context. Furthermore, the church cannot become 'world' and cannot dictate to secular institutions what policies and practices should be promoted. The church, however, should be an exemplary community embodying the principles of love, care and reconciliation. In this respect, the ecclesiology of Van de Beek raises a valid point. Having said that, it must be conceded that the church should expose a public awareness. Theology cannot be viewed as public theology but public awareness is part of theology (Smit 2005:41).

- Van de Beek's view of the church as a Eucharist and eschatological community is valuable and worthy to consider. This viewpoint describes the uniqueness of the church in the world. The church is much more than an activist civil society. First and foremost, the spirituality of Christians is unfurled by the notion of the 'otherworldliness' of the Christian community. Essentially, Christians are indeed strangers and pilgrims in the world with a higher purpose and destination. Faith and worship should express this notion and, in this respect, the church can also be described as a therapeutic community (Vorster 2014:156).

- The idea of a twofold character of the Kingdom is another valuable contribution by Van de Beek. This idea has become a paradigm in the theology of the Kingdom. Research about the concept of the Kingdom of God in recent times mainly focuses on the question of whether the Kingdom and its moral relevance are a future or a present reality or both. Malan (2014:1) phrases the question as follows: 'The Kingdom of God: utopian or existential?' The diagnosis regarding research on this subject presented by Ladd (1961:25) a few decades ago can still be regarded as valid. According to Ladd, two main lines of thought can be distinguished. To present a view on the ethics of the Kingdom, a short summary of his analysis is necessary. Non-eschatological interpretations of Ritschl (1822-1889), Schweitzer (1875-1965) and Weiss
(1863-1914) viewed the Kingdom as an immanent historical reality, which can and should be established by the moral actions of humans on the basis of the ethics of Christ. Van de Beek (2012:126) also refers to these authors. Influenced by the rationalism of the Enlightenment, the Kingdom is not viewed as a spiritual reality of the future but indicates a new humanity of peace and justice that can be developed in this world. This way of thinking of a realised eschatology views the kingdom as a metaphor that describes the political tasks of Christianity to pursue a society of peace and justice. This standpoint was extremely influential in political theologies of the late 20th century (Fierro 1977). Van de Beek rightly criticises this approach. The Kingdom is not a historical reality that should be manifested by the ethical and social actions of people, according to the ethics of Christ. It entails much more.

\section{One-sided approach}

However, the present character of the Kingdom is also of importance in dealing with the issue of the church acting as a moral agent. The main problem concerning the view of Van de Beek (2012:141) about the Kingdom is that he focuses on one aspect of the Kingdom and develops his ecclesiology within these exact parameters. This approach is one sided. Van de Beek views the church as an eschatological community. He makes a distinction between the church and eschatology. In his view, the church and the Kingdom are identical. This view nullifies the present reality of the Kingdom. New Testament theology about the Kingdom in recent years indicated a twofold character of the Kingdom (Ladd 1961:25). This idea became prominent in Protestant thought (Vorster 2017a:1) and is described by Küng (1992:56) as a futurist-presentist eschatology. Beach (2012:660) mentions the 'already' and the 'not yet' of the Kingdom. According to his viewpoint, the Kingdom was already realised in principle with the coming and resurrection of Christ. With Christ the Kingdom has come. The reign of God over all creation is established but the final victory of his reign will take place with the consummation. Meanwhile, signs of the Kingdom will be erected everywhere where the Name of God is proclaimed. The most important sign is the formation of the church with a threefold office of king, prophet and priest - the threefold office of Christ (Welker 2013:209).

The idea of a present reality of the Kingdom has important implications for a definition of the church. The church should not be referred to in general terms, such as a universal community. The church comprises both the instituted body of believers (the local church) and Christians in the world (the universal church). The local (visible) church bears all the attributes of the universal church. In view of these insights mentioned above, the author chooses a model that describes the instituted church as an 'electric power plant'. This metaphor was introduced by Duvenage (1970:206) in a thesis 
about the relationship between the church and nation in South Africa. He developed this metaphor further by including core elements of the ecclesiology of neo-Calvinism. This metaphor can be enriched with the views of Barth, Moltmann, Hauerwas and Bosch (Vorster 2017b:22). As Hauerwas (1995:35) and Bosch (1991:172) contend, the instituted church should be an exemplary community. The church should act as an example of a peaceable Kingdom with established social ethics (Hauerwas 1981:72; 1983:99; 2001:150). ${ }^{3}$ But, the church - as the first sign of the Kingdom establishes other signs of the Kingdom by proclaiming in its kingly office the kingship of Christ over all creation. This entails the preaching of the norms and values of Christ with regard to science, economy, politics and culture. In its prophetic office, the church has to preach redemption, hope and peace to a broken world and society. In its priestly capacity, the church has to act as stewards of the love of Christ and should manifest an attitude of servanthood amongst people. The church can, therefore, be viewed as the people of the present Kingdom with the divine calling to be a prophetic, therapeutic and a moral community. In addition, the church should act as an example of a peaceable Kingdom with established social ethics (Hauerwas 1981:72; 1983:99; 2001:150). The church should in this respect act as a civil society by setting the example of a reconciled, loving and peace-seeking community. Society at large should be able to identify a model of love, fairness, justice and sound morality in a local congregation. Van de Beek (2012:135) reduces the task of the church into praying for the government. In this way, the richness of an exemplary church in the world is diminished and the prophetic voice is silenced.

Furthermore, the church as a part of civil society should act as a moral agent by testifying to the noble principles of the kingdom, as Barth (1946:33) and Moltmann (2012:40) remind us. The church is not the Kingdom but the first sign of the Kingdom and establishes signs of the Kingdom by proclaiming in its kingly office the kingship of Christ over all creation. This entails the preaching of the norms and values of Christ with regard to science, economy, politics and culture. The church can, therefore, be viewed as the people of the present Kingdom with the divine calling to be a prophetic, therapeutic and a moral community. By acting as people of the present Kingdom, the instituted church can act like an 'electric power plant' that generates energy for social action. The life of the church, worship, preaching, diaconate and the

\footnotetext{
3.The idea of Hauerwas is valuable and useful. However, Hauerwas $(2002: 341)$ tend to limit the prophetic calling of the church by maintaining that the main task of the to limit the prophetic calling of the church by maintaining that the main task of the
church is to act as a body with social ethics - an alternative story. In its public church is to act as a body with social ethics - an alternative story. In its public
testimony and ministry, the church should act as a moral community and should be testimony and ministry, the church should act as a moral community and should be
an example of a peaceable Kingdom. The prime task of the church is to follow Jesus' an example of a peaceable Kingdom. The prime task of the church is to follow Jesus'
way of life and teaching, to show the world that it is 'world'. God becomes visible through the holiness of the church; the church must leave it to God to change the world. The heart of the church is worship. His emphasis on the church as an example of a peaceful, alternative community is valuable and should be viewed as an important aspect of the prophetic calling of the church. However, this idea cannot comprise the sole calling of the church modelled on the threefold office of Christ. Moltmann (2012:31) criticises the view of Hauerwas with regard to the role of the church in society. He points out that the righteousness and justice of God in the church in society. He points out that the righteousness and justice of God in the world 'does not begin with the justification of the perpetrators of sin; it begins with the justification of the victims of sin, injustice and violence.' Justification cannot be reduced to the forgiveness of sins. The forgiveness of $\sin$ is one part of justification. The church should, therefore, protest against all forms of injustice in society. In contrast with the idea of Hauerwas who views the church as a peaceable kingdom', Moltmann (2012:33) makes a case for the church as a 'peacemaking kingdom'. We are not told: 'Blessed are the peaceful' but: 'Blessed are the peacemakers'.
}

prophetic witness of the church must be focused on the development of an awareness, values, knowledge, willingness and the abilities of individual Christians.

However, this metaphor of 'the church as an electric power plant' contains an additional important element. An electric power plant generates power, and the power is transmitted to a city by electric cables that are connected to all parts of a region or a city in order to produce light and energy where it is needed. This metaphor entails that Christians - equipped by worship and ministry in the instituted church - can be described as the 'cables' who bring light and energy to a society. In the instituted church, 'energy' is generated by worship, the ministry of the Word and the sacraments. Christians as the 'cables' of the 'electric power plant' should then relay this energy to society members by way of social actions, according to the moral principles flowing from the reign of Christ, as expressed in the Word and the sacraments. The instituted church should, therefore, be an empowering community in which Christians are equipped and trained to be active society members. To summarise, the church should be an example of high moral standard and should testify about the moral implications of the reign of Christ; but more importantly, it should be a community where Christians are equipped to fulfil their calling as moral agents in a society. As such, the church can act as a moral community in a society. In this way the 'spiritual character' of the church is maintained as van de Beek pleads for but with the added dimension of being a moral agent without compromises to politics and ideologies.

\section{A questionable hermeneutics of the Old Testament}

Van de Beek (2012:137) states that the Old Testament has been fulfilled in the New Testament and that the ethics of the Old Testament must be interpreted in a Christological sense. There is no Torah anymore. This view introduces a new vision on the hermeneutics of the Old Testament and can be questioned. The Old Testament is fully Scripture and contains a unique theology and ethics. The history of revelation flows though the Old Testament, irrespective of different historical contexts and genres of material. A theology is presented in the Old Testament and focuses on the coming of the Messiah a theology in its own right. In this process, the ethics of the Old Testament is developed as an ethics for the people of God and for the nations, according to the universal covenant. This idea is well developed in a recent book written by VanDrunen (2014). He maintains that because of the natural law, all nations are called forth to effectuate the moral law given to all people by God. All morals come from God and all nations have to oblige. The Old Testament ethics have a clear character and direction and should not be devaluated in favour of the ethics of the New Testament.

God calls on all nations to be fair and just in the treatment of the poor and the needy. He expects justice and peace. He prescribes a moral lifestyle and judges the nations when they 
live in an ungodly manner. He rejects their power hunger and ungodliness. Israel should be an example to the nations in their treatment of the vulnerable. They have received clear instructions on how to live. These instructions are deeply embedded in the 10 Commandments and become clear when the Commandments are viewed within its synecdoche character. The Eighth Commandment, for example, deals with theft but according to the synecdoche character of the Eighth Commandment, it also establishes the right to own property and instructs people to be fair in business transactions, to pay a fair wage, to be satisfied with what they have and to avoid greediness (De Bruyn 1992:227; Douma 1996:285). The people of God had to transfer these moral ideals to the nations and the prophets reprimanded them to act according to their calling by God.

The importance of the Old Testament theology and ethics for the church as a moral agent does not feature in the ecclesiology of Van de Beek. This deficiency is because of a questionable hermeneutic of the Old Testament.

\section{Conclusion}

The relationship between eschatology and reality with reference to the role of the church in society has been developed adequately by Moltmann (2012). Van de Beek raises a valuable and important point by defining the church as an eschatological and Eucharistic community. However, it does not end there. The church - as a Eucharistic and an eschatological community - raises hope and contributes to an ethic of hope, as Moltmann maintains. Ethics have a deep influence on the development of an orderly and peaceful society. The church has to position itself not beside a society but within a society as a moral agent. Related to this exemplary character of the church in society, the church should address a society as a moral agent with a prophetic voice, which comprises preaching in the instituted church and the testimony of Christians on many social terrains where they act in their kingly, prophetic and priestly offices. The limitations of the voice of the church are correctly identified by Van de Beek in his criticism of public theology as the sole expression of theology, but these limitations cannot and should not be used to silence the church as a moral agent in the world. Eschatological and Eucharistic communities are essentially pilgrims but not silent pilgrims with no mandate.

It is also difficult to see how the ecclesiology of Van de Beek addresses the current wave of secularism effectively. Christians should not only proclaim to the world that the resurrected Christ rules but should also indicate the consequences of this rule when lives are lived immorally. Without surrendering its primary status as a pilgrim and a stranger in this world, the plight of the church should not just become another social role-player. The church should have a positive influence on its surroundings in its pilgrimage and should stand firm against secularism by being a responsible moral agent.

\section{Acknowledgements Competing interests}

The author declares that he has no financial or personal relationships which may have inappropriately influenced him in writing this article.

\section{References}

Barth, K., 1922, Die Römerbrief, Kaiser, München.

Barth, K., 1946, Christengemeinde und Bürgergemeinde, Theologische Studien 20, Evangelische Verlag, Zollikon.

Beach, M., 2012, 'The kingdom of God: A brief exposition of its meaning and implications', Mid-American Journal of Theology 23(2012), 53-76.

Berkhof, H., 1959, Christus de zin van het wereldgeschiedenis, Callenbach, Nijkerk.

Bishop, J., 2016, Working towards a definition of public theology, viewed 03 July 2017 from https://jamesbishopblog.com/2016/06/06/working-towards-a-definitionof-public-theology/

Bosch, D., 1991, Transforming mission, paradigm shifts in theology of mission, Maryknoll, NY.

Brunner, E. \& Barth, K., 1946, Natural theology, Geoffrey Bless, London.

De Bruyn, P.J., 1992, The ten commandments, Varia, Midrand.

Douma, J., 1996, The ten commandments, manual for the Christian life, transl. N.D. Kloosterman, P\&R Publishing, Philipsburg.

Duvenage, S.C.W., 1970, 'Die geïnstitueerde kerk en die Suid-Afrikaanse volkskultuur', Koers 37(3 \& 4), 206-218.

Fierro, A., 1977, The militant gospel. An analysis of contemporary political theologies, SCM Press, London.

Gutierrez, G., 1985, A theology of liberation, SCM Press, New York.

Harvie, T., 2009, Jürgen Moltmann's ethics of hope: Eschatological possibilities for moral action, Ashgate, Farnham.

Hauerwas, S., 1981, A community of character toward a constructive Christian social ethic, University of Notre Dame Press, Notre Dame.

Hauerwas, S., 1983, The peaceable kingdom: A primer in Christian ethics, University of Notre Dame, Notre Dame.

Hauerwas, S., 1986, The peaceable kingdom: A primer in Christian ethics, University of Notre Dame Press, Notre Dame.

Hauerwas, S., 1995, In God's company: The church as polis, University of Notre Dame Press, Notre Dame.

Hauerwas, S., 2001, 'The church as God's new language', in S. Hauerwas, J. Berkman \& M.C. Cartwright (eds.), The Hauerwas reader, Duke University Press, Durham.

Hauerwas, S., 2002, 'The church as God's new language', in S. Hauerwas, J. Berkman \& M.C. Cartwright (eds.), The Hauerwas reader, Duke University Press, Durham.

Hauerwas, S. \& Willimon, W.H., 1989, Resident aliens: A provocative Christian assessment of culture and ministry for people who know that something is wrong, Abingdon Press, Nashville, TN.

Koopman, N., 2012, 'Public theology in a suffering world', in E. Van de Borght \& P. Van Geest (eds.), Strangers and pilgrims on earth, Essays in honour of Bram van de Beek, pp. 887-896, Brill, Leiden.

Küng, H., 1992, The church, Burns and Oates, Kent.

Ladd, G.E., 1961, The gospel of the kingdom of God, Eerdmans, Grand Rapids, MI.

Malan, G.J., 2014, 'The kingdom of God: Utopian or existential?', HTS Teologiese Studies/Theological Studies 70(3), Art \#2109, 1-9. https://doi.org/10.4102/ htsv703.2109

Moltmann, J., 1990, The way of Jesus Christ: Christology in messianic dimensions, SCM Press, London.

Moltmann, J., 2012, Ethics of hope, SCM Press, London.

Mouw, R.J., 2000, 'Foreword', in G. Van Gelder (ed.), The essence of the Church, a community created by the Spirit, pp. 7-8, Baker Books, Grand Rapids, MI.

Rahner, K., 1972, 'Grunlinien einer systematischen Christologie', in K. Rahner \& W. Thüsing (eds.), Christologie - Systematisch und exegetisch, pp. 17-78, Questions disputate 55, Herder, Basel.

Shaull, R., 1969, Uitdaging aan kerk en maatschappij, Bosch \& Keuning, Baarn.

Smit, D., 2005, 'No ulterior motive - And public theology?', in E.A.J.G. Van den Borgth (ed.), Religion without ulterior motive, pp. 21-45, Brill, Leiden.

Van de Beek, A., 2005, 'Religion without ulterior motive', HTS Theological Studies 61(1 \& 2), 517-529. https://doi.org/10.4102/hts.v61i1/2.425

Van de Beek, A., 2012, Lichaam en geest van Christus. De theologie van die kerk en de Heilige Geest, Meinema, Zoetermeer.

Van den Borght, E.A.J.G., 2005, Religion without ulterior motive, Brill, Leiden.

VanDrunen, D., 2014, Divine covenants and moral order: A biblical theology of natural law, Eerdmans, Grand Rapids, MI. 
Van Wyk, J.H., 2015, Teologie van die koninkryk van God. Studies in dogmatiek en etiek, Administrative Buro of The GKSA, Potchefstroom.

Verkuyl, J., 1971, Breek de muren af! Om gerechtigheid in de rassenverhoudingen, Bosch en Keuning, Baarn.

Vorster, J.M., 2014, Christelike etiek in 'n sekulariserende gemeenskap, AOSIS, Cape Town.
Vorster, J.M., 2017a, 'Kingdom, covenant, and human rights', In die Skriflig 51(2), a2257. https://doi.org/10.4102/ids.v51i2.2257

Vorster, J.M., 2017b, 'Kingdom, church and civil society - A paradigm for civil action', in M. Welker, N. Koopman \& J.M. Vorster (eds.), The church and civil society. German and South African perspectives, pp. 15-32, SUN Press, Stellenbosch.

Welker, M., 2013, God the revealed. Christology, Eerdmans, Grand Rapids, MI. 